\title{
ARTICLE
}

\section{STUDIES OF KINETICS AND THERMODYNAMIC PARAMETERS OF CASHMERE DYEING WITH BIO-PREPARATION OF URTICA CANNABINAL}

\author{
Tserendulam S. *I, Ganchimeg Yu. ${ }^{2}$, Nadmid G. ${ }^{1}$ and Soyol-Undrakh Kh. ${ }^{1}$ \\ ${ }^{I}$ Research and Development Institute of Light Industry, \\ Mongolian University of Science and Technology, Ulaanbaatar, Mongolia \\ ${ }^{2}$ Chemical Engineering Department, School of Applied Sciences, \\ Mongolian University of Science and Technology,Ulaanbaatar, Mongolia
}

\begin{abstract}
In this study, dyeing Mongolian cashmere with bio-preparation extracted from Urtica cannabina L. was investigated. Dyeing experiments were carried out under varying $\mathrm{pH}$, temperature and contact time. The results have been used to investigate the kinetic and thermodynamic parameters of dyeing cashmere. This process is $\mathrm{pH}$ dependent and it has been found that the most suitable condition is $p H 4.5$. Increase in adsorption capacity with increase in temperature indicates that the dyeing process is endothermic. Thermodynamic parameters like standard affinity $(\Delta \mu)$, standard enthalpy $(\Delta H)$ and standard entropy $(\Delta S)$ were evaluated.
\end{abstract}

Keywords: Cashmere; dyeing; natural dye; adsorption; nettle;

\section{INTRODUCTION}

Cashmere is a natural fibre taken from the cashmere down. It is one of the most luxurious and rare fibres. Cashmere yarn is renowned for being light, airy, delicate, glossy and its warmth. Thanks to these properties, cashmere is used as a raw material for luxury woven or knit products. Around $30.0 \%$ of the world cashmere is produced in Mongolia. As of 2015, 43.2\% of the total livestock of Mongolia were cashmere goats. The Mongolian goat breed is often reddish, red, grey, black, dark brown, and white [1-3].

The process of producing a cashmere apparel includes a number of steps starting with fibre preparation to garment processing. Among the many production steps, dyeing is essential in order to produce cashmere garments, especially with natural dyeing for "Eco-organic product" [4].

International awareness about environment, 
ecology and pollution control led to an upsurge in the use of natural dyes in the middle of the 20th century.

During the last few decades, increasing attention has been given by researchers all over the world towards various aspects of natural dye applications $[5,6]$.

Flora- and animal-based natural dyes/biopreparations are believed to be eco-friendly, safe and a viable substitute to synthetic colorants because of their non-toxic, noncarcinogenic and biodegradable nature [7, 8]. Moreover, natural dyes neither cause pollution nor waste water problems.

Natural dyes can give suitable and elegant colours through to the brightest colour to the fibers, yarns and fabrics. The major part of natural dyes are anthraquinone, anthocyanin and flavonoid dyes, or polyphelolic compounds most of which have yellow, red and brown shades (Bechtold and Mussak., 2009) [9].

Urtica.Cannabina L. is commonly known as a nettle which grows almost everywhere in Mongolia. The herb grows from 1.5-3.0 $\mathrm{m}$ in $[10,11]$ height. The herb is the chief source of Mongolian nettle and finds application in folk medicine and food. In spring, when the plant is young it has a rich content of vitamin $\mathrm{C}$, which can be used as a raw material for hair shampoo and conditioner and can also be used for colouration of textile materials.

Major active constituents of Urtica. Cannabina.L are protein chlorolphylls $\mathrm{a}, \mathrm{b}$, $\mathrm{c}$ and quercetin, luteolin, tannic and gallic acids, free amino acids, vitamins $\mathrm{A}, \mathrm{C}, \mathrm{D}, \mathrm{E}$, F, K, P and B-Complexes as well as thiamin, riboflavin, niacin and these plants also high a content of such metals as selenium, zinc, iron and magnesium.

Most of the natural yellows are derivatives of hydroxyl and methoxy substituted flavones and isoflavones. Flavonoids add brilliant colours to wool and silk, the structure of which is given in Figure 1.
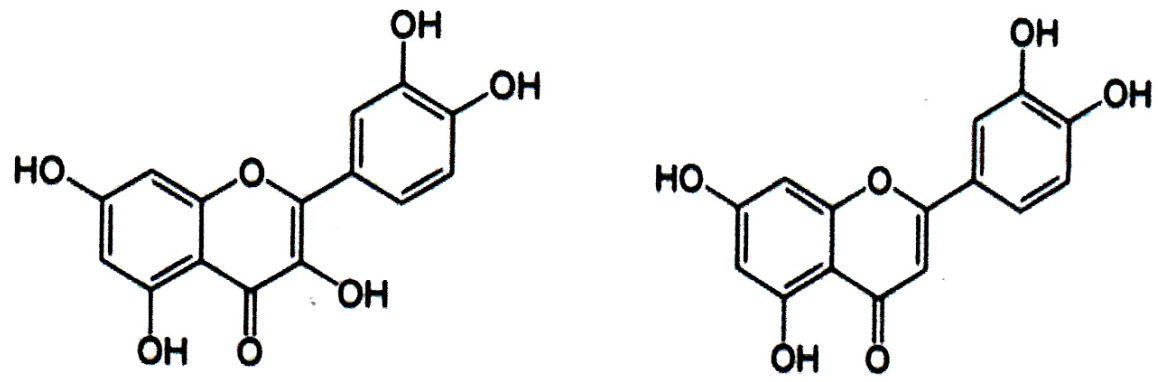

Figure 1. Colouring agents: Quercetin, Luteolin of Urtica

The objectives of this work are: (1) to determine optimum condition of dyeing; (2) to estimate thermodynamic and kinetic

\section{MATERIALS AND METHODS}

Natural light grey dehaired cashmere (fineness $16.32 \mathrm{mkm}$, average length $38.6 \mathrm{~mm}$ ) by the Gobi company of Mongolia was scoured with an aqueous nonionic surfactant solution parameters of the process; and, (3) to determine a suitable model describing the isotherms.

at a temperature of $45^{\circ} \mathrm{C}$ for 20 minutes, then it was throughly rinsed with cold water and air dried at room temperature. 


\section{Plant, dye bio-preparation}

Fresh natural Urtica cannabina. L leaves and stems were collected from the experimental garden of the Botanical Institute of Mongolia. The leaves were dried in a dark room under room temperature $\left(20-25^{\circ} \mathrm{C}\right)$. After that, dried leaves were crushed into fine powder. This powder was used in all succeeding experiments to extract bio-preparation Urtica cannabina. $L$. for dyeing. Dyeing bio-preparation solutions by water were prepared for 60 minutes, at a temperature of $80^{\circ} \mathrm{C}$ with the $\mathrm{M}: \mathrm{L}$ ratio at $1: 30$ [12].

\section{Dyeing Process}

The dyeing of cashmere fibres was carried out at $\mathrm{pH}$ 5.0. Laboratory grade acetic acid $\left(\mathrm{CH}_{3} \mathrm{COOH}\right)$ was used for adjusting the $\mathrm{pH}$ of the dyeing bath. The dyeing process of cashmere fibers was carried out at $\mathrm{pH} 4.5$ condition using a bath containing extracted Urtica cannabina L. bio-preperation solution at a ratio of 1:50 for cashmere fiber and dyeing bio-preparation. The dyed cashmere fiber were washed with water and dried at room temperature. After which the surface analysis of the cashmere was carried out on undyed and dyed cashmere samples.

\section{Thermodynamic studies}

The thermodynamic parameters of the process, such as standard affinity, $\Delta \mu^{0}(\mathrm{~kJ} /$ mole), standard entropy, $\Delta \mathrm{S}^{0}(\mathrm{~J} / \mathrm{mol} \cdot \mathrm{K})$ and standard enthalpy, $\Delta \mathrm{H}^{0} \quad(\mathrm{~kJ} / \mathrm{mole})$ were calculated by using the following equation $[1$, 2, 3]:

$$
\begin{aligned}
& -\Delta \mu^{0}=R T \ln \frac{D f^{\mathrm{m}}}{V} \times D_{s}=\mathrm{RT}_{\ln } \mathrm{K}_{\mathrm{c}} \\
& \mathrm{K}_{\mathrm{c}}=\frac{\mathrm{C}_{\mathrm{ad}}}{\mathrm{C}_{\mathrm{e}}} \times \frac{V}{m} \\
& \operatorname{lnK}_{\mathrm{c}}=\frac{\Delta \mathrm{H}^{0}}{-\mathrm{RT}}+\frac{\Delta \mathrm{S}^{0}}{\mathrm{R}}
\end{aligned}
$$

where, $\mathrm{K}_{\mathrm{c}}$ is the equilibrium constant, $\mathrm{C}_{\mathrm{ad}}$ is the adsorbed dye concentration $(\mathrm{mg} / \mathrm{l})$, $\mathrm{C}_{\mathrm{e}}$ is the equilibrium dye concentration, $\mathrm{V}$ is the volume (l) and $\mathrm{m}$ is the mass of the cashmere fiber $(\mathrm{g})$; $\mathrm{R}$ is the gas constant ( 8.314 $\mathrm{J} \mathrm{mol}^{-1} \mathrm{~K}^{-1}$ ); $\mathrm{T}$ is the absolute temperature (in Kelvin).

The variations of $\Delta \mathrm{H}^{0}$ and $\Delta \mathrm{S}^{0}$ were calculated from the slopes and intercepts of the plot of $\operatorname{lnKc}$ versus 1/T are linear, respectively.

\section{Kinetics of dyeing}

Kinetic studies were carried out for the time periods ranging from 30 minutes to 100 minutes, using a bath containing extracted Urtica cannabina. $L$ bio preperation solution at 1:50 M:L ratio. Kinetics of dyeing was studied by fitting first-order and second order reactions to experimental data. The pseudo first-order model is given in the following equation [4]:

$$
\log \left(q_{t}-q_{e}\right)=\log q_{e}-\frac{k_{1} t}{2.303}
$$

The linear form of pseudo second order rate equation is given as follows [5]:

$$
\frac{\mathrm{t}}{\mathrm{q}_{\mathrm{t}}}=\frac{1}{\mathrm{q}_{\mathrm{t}}}+\frac{1}{\mathrm{k}_{2} \mathrm{q}_{\mathrm{e}^{2}}}
$$

where, $\mathrm{k} 1(\mathrm{~min}-1), \mathrm{k} 2(\mathrm{~g} / \mathrm{mg} \mathrm{min})$ are rate constants of pseudo-first order, pseudo-second order rate equation, qt and qe the amounts of dye into cashmere fibre at time $\mathrm{t}$ and equilibrium, respectively ( $\mathrm{mg} / \mathrm{g}$ );

The amounts of dye uptake by cashmere fiber were calculated using the following equation $[6,7]$ :

$$
\begin{aligned}
& \mathrm{q}_{\mathrm{t}}=\frac{\left(\mathrm{C}_{0}-\mathrm{C}_{\mathrm{t}}\right) \mathrm{V}}{\mathrm{m}} \\
& \mathrm{q}_{\mathrm{e}}=\frac{\left(\mathrm{C}_{0}-\mathrm{C}_{\mathrm{e}}\right) \mathrm{V}}{\mathrm{m}}
\end{aligned}
$$

where, $q_{t}$ and $q_{e}$ are the amounts of dye in the cashmere fiber at time $\mathrm{t}$ and equilibrium, respectively $(\mathrm{mg} / \mathrm{g}) ; \mathrm{C}_{0}, \mathrm{C}_{\mathrm{t}}$ and $\mathrm{C}_{\mathrm{e}}$ are the initial, time $\mathrm{t}$ and equilibrium concentration of dye in the solution $(\mathrm{mg} / \mathrm{l}) ; \mathrm{V}$ is the volume of dye bio preparation solution (L); $\mathrm{m}$ is the mass of cashmere fiber $(\mathrm{g})$ and $\mathrm{t}$ is the sorption period ( $\mathrm{min})$. 
Isotherm model

Langmuir and Freundlich isotherm model is commonly used to reflect the performance of adsorbents in adsorption processes.

Langmuir model assumes monolayer adsorption given by [8]:

$$
\frac{\mathrm{Ce}}{\mathrm{qe}}=\frac{1}{\mathrm{Q}^{0} \mathrm{~b}}+\frac{\mathrm{Ce}}{\mathrm{Q}^{0}}
$$

Freundlich isotherm model assumes multilayer adsorption given by [9]:

$$
\ln q_{e}=\ln K f+b f \ln C e
$$

where, $\mathrm{Q}^{\circ}(\mathrm{mg} / \mathrm{g})$ is the maximum adsorption capacity, $\mathrm{b}$ is the Langmuir constant and $\mathrm{Kf}(1 / \mathrm{g})$ and $\mathrm{n}$ are Freundlich constants [13$18]$.

in Fig. 2.

From the fig 2, obviously found dyeing cashmere was strongly $\mathrm{pH}$ dependent, and that dye exhaustion was superior at $\mathrm{pH}$ 5.0. $\mathrm{pH}$ on dyeing cashmere, the $\mathrm{pH}$ was varied 4.5 to 6.5. The experimental results are presented

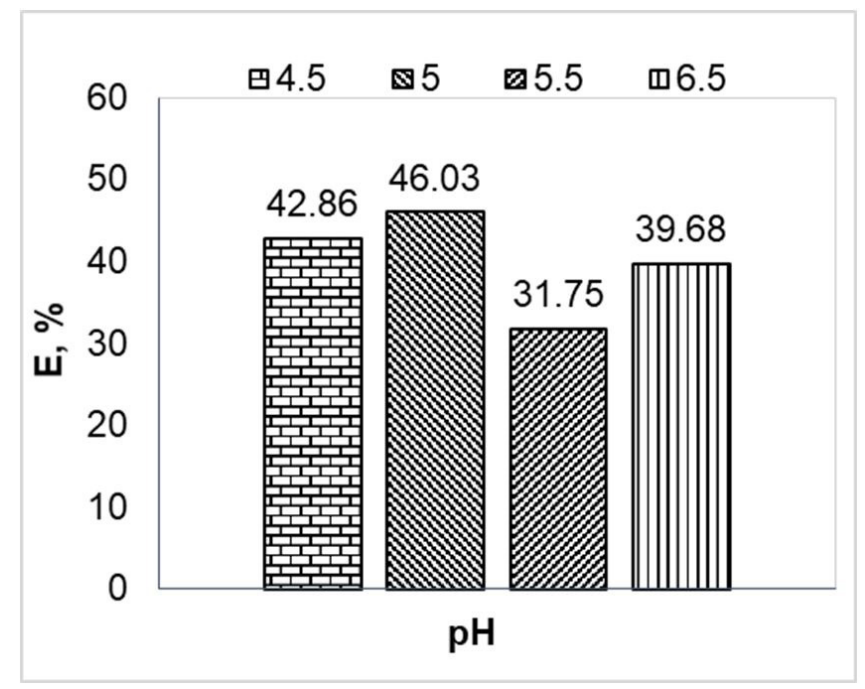

Figure 2. Effect of dye bath $\mathrm{pH}$ on dye exhaustion on cashmere fiber (initial concentration $630 \mathrm{mg} / \mathrm{l}$, temperature $353 \mathrm{~K}, t=60 \mathrm{~min}$ )

But dye exhaustion decreased from $46.03 \%$ to $31.75 \%$ when the dyeing $\mathrm{pH}$ range conditions was $4.5,5.5,6.5$. Hence, $\mathrm{pH} 5.0$ was taken for further experimental work. 
Effects of dyeing temperature and time periods on exhaustion of bio-preparation on cashmere fibre

The effect of temperature on dyeing cashmere is investigated at pH 5.0 condition.

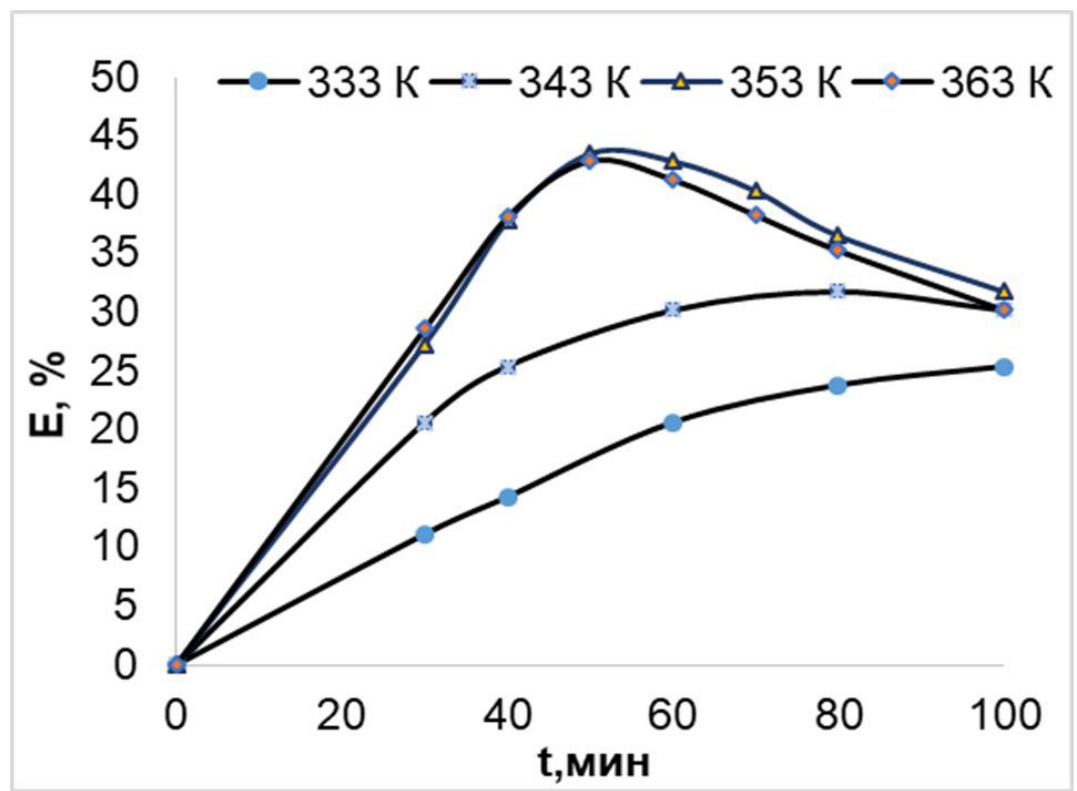

Figure 3. Effects of dyeing temperature and time period on exhaustion of bio-preparation on cashmere fibre (initial concentration $630 \mathrm{mg} / \mathrm{l}, \mathrm{pH}=5.0, \mathrm{ML}$ 1:50)

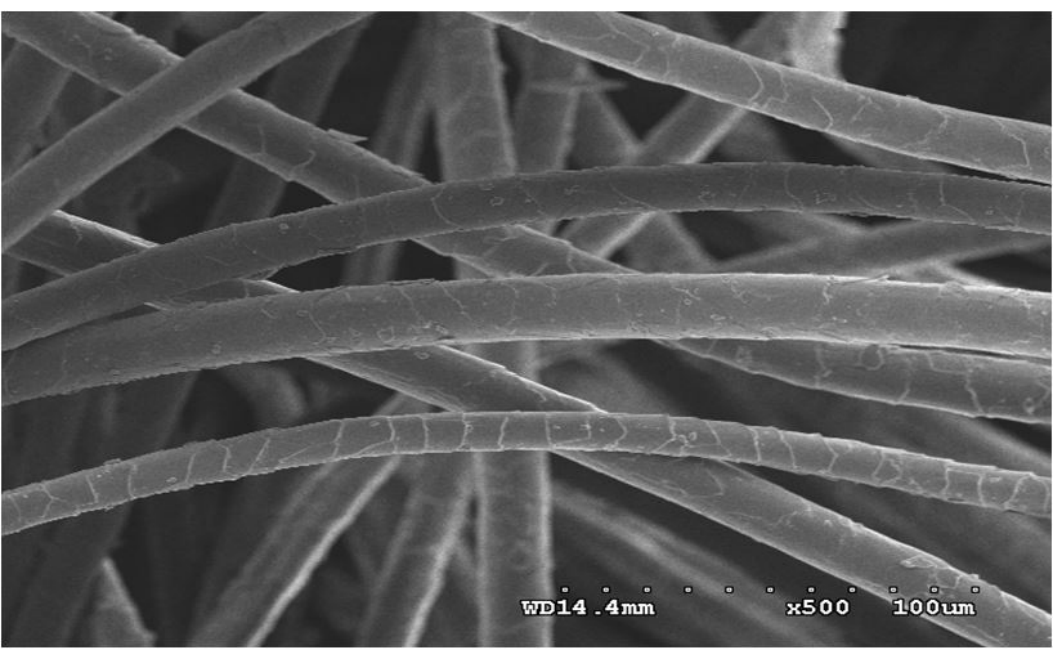

Figure 4. Undyed cashmere picture by the SEM 
In figure 3, dye exhaustion is increased by raising the temperature. The maximum value of dye exhaustion is reached at about $42.85 \%$ at $353 \mathrm{~K}, 60 \mathrm{~min}$. And the dyeing temperature at $363 \mathrm{~K}$, dyed at $40 \mathrm{~min}$ is $38.1 \%$, and at $50 \mathrm{~min}$ it is $42.86 \%$. But the observed dyed cashmere fibers were felted because the fiber cuticle was damaged when temperature was higher.

\section{https://www.mongoliajol.info/index.php/PMAS}

The cashmere fibre were dyed at $80^{\circ} \mathrm{C}$ and $90^{\circ} \mathrm{C}$ and with a duration of 50 and 60 minutes respectively, so as to study the dyeing time and temperature dependences in changing the surface morphology of the wool fibre under the influence of dyeing conditions. After dyeing, the surface morphology of the wool fibre was studied using a scanning electron microscope (Figures 4 and 5).

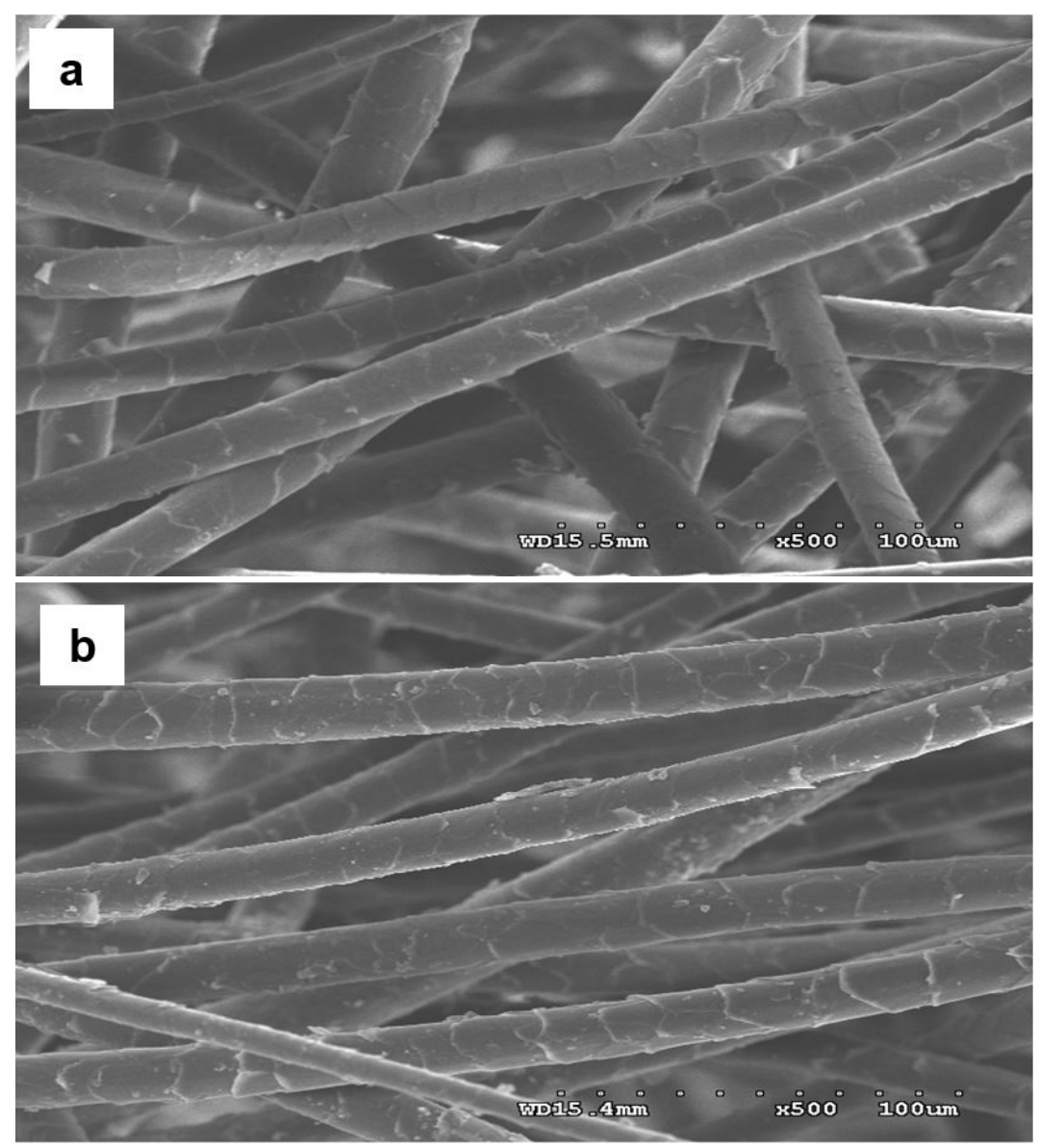

Figure 5. Dyed cashmere fibre's picture by the SEM a) dyed at $80^{\circ} \mathrm{C}, 60 \mathrm{~min} ;$ b) dyed at $90^{\circ} \mathrm{C}, 50 \mathrm{~min}$

Figure 4 shows the SEM picture of undyed cashmere fibre in which the escarpments are prominent and well defined. The undyed cashmere fibre surface may be described as a smooth fibre surface.

Figures 5(a) and (b) are the SEM pictures of cashmere fibres dyed at $80^{\circ} \mathrm{C}$ for 60 minutes and at $90^{\circ} \mathrm{C}$ for 50 minutes respectively. The appearance of those fibres were quite similar to the untreated fibre. There was no visible change or damage on the scale structure when dyed at $80^{\circ} \mathrm{C}$ for 60 minutes, but the fibre cuticle's scale dyed at a temperature of $90^{\circ} \mathrm{C}$ for 50 minutes was slightly lifted and was 
observed to be broken.

The dye exhaustion of cashmere fibre dyed at $353 \mathrm{~K}$ for different time periods has been carried out. The time of dyeing is calculated as $60 \mathrm{~min}$. It has been observed that as the time of dyeing increases from $30 \mathrm{~min}$ after which equilibrium is achieved. A similar trend was reported for the kinetics and thermodynamics of dye extracted from Arnebia Nobilis Rech.f. on wool [19] and dyeing kinetics of wool yarn with Rubia Tinctorium L. [20].

Therefore, $353 \mathrm{~K}$ and 60 minutes were chosen as suitable temperature and time for cashmere dyeing with bio-preparation.

\section{Thermodynamic and kinetic parameters}

Experimental results of the effects of temperature and time were used to calculate thermodynamic and kinetic parameters.

Thermodynamic parameters such as change in standard affinity $\left(\Delta \mu^{0}\right)$, standard enthalpy $\left(\Delta \mathrm{H}^{0}\right)$ and standard entropy $\left(\Delta \mathrm{S}^{0}\right)$ were evaluated by the equation $(1,2,3) \cdot \Delta \mathrm{H}^{0}$ and $\Delta \mathrm{S}^{0}$ were calculated from the slope and intercept of the Vant Hoff's plot of $\ln _{\mathrm{c}}$ verses $1 /$ T as shown in Fig. 6.

The thermodynamic parameters are given in Table 1.

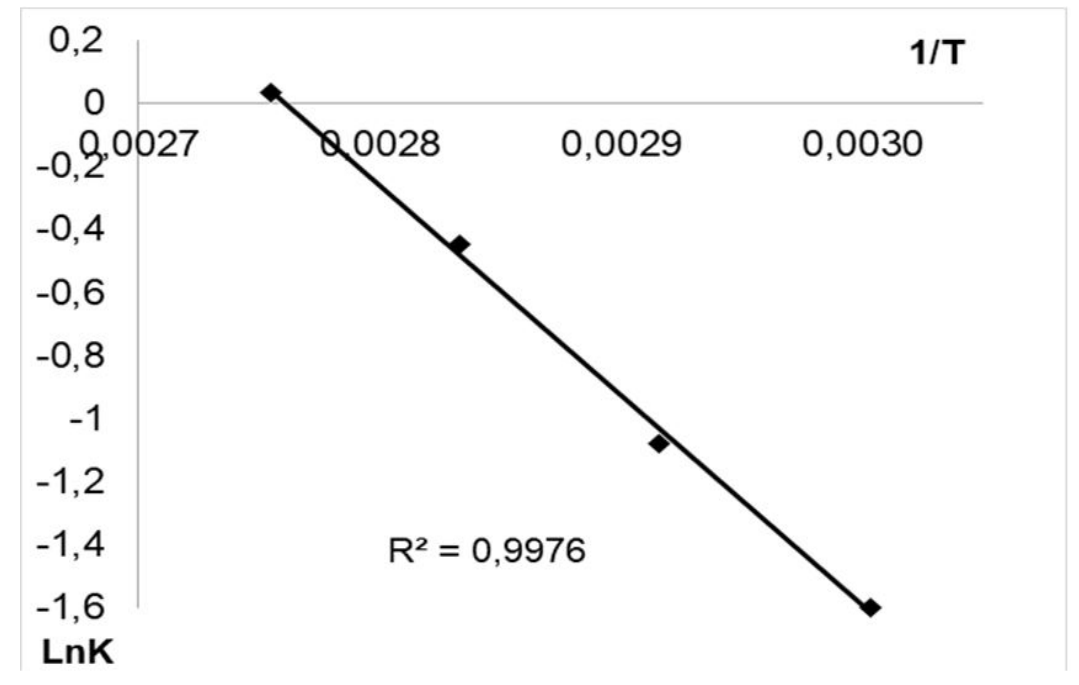

Figure 6. Vant-Hoff's plot at concentration of $630 \mathrm{mg} / \mathrm{l}$

Table 1. Thermodynamic parameters for cashmere dyeing with Urtica cannabina. L

\begin{tabular}{|c|c|c|c|c|}
\hline Temperature, (K) & $\begin{array}{c}\text { Bio preparation } \\
\text { concentration, mg/l }\end{array}$ & $\begin{array}{c}\Delta \mu^{0}, \\
(\mathrm{~kJ} / \mathrm{mol})\end{array}$ & \multirow{2}{*}{$\begin{array}{c}\Delta \mathrm{H}^{0}, \\
(\mathrm{~kJ} / \mathrm{mol})\end{array}$} & $\begin{array}{c}\Delta \mathrm{S}^{0}, \\
(\mathrm{~kJ} / \mathrm{mol} \cdot \mathrm{K})\end{array}$ \\
\hline 353 & & -13.25 & & \\
\cline { 1 - 1 } 343 & \multirow{3}{*}{630} & -11.38 & \multirow{2}{*}{63.5} & 151.4 \\
353 & & -9.83 & & \\
& & -8.75 & & \\
& & & &
\end{tabular}

From Table 1, positive values of $\Delta \mathrm{H}^{0}$ the negative values of $\Delta \mu^{0}$ have been increasing indicate that the dyeing of cashmere with Urticacannabina $L$. is an endothermic process. slowly with a rise in temperature.

The increasing of the dyeing temperature

The negative values of $\Delta \mu^{0}$ has been shown where the dyeing process is spontaneous and will lead to higher dye affinity up to a certain temperature limit, above which the dye uptake $-10-$ 
will gradually reduce. This suggests that the adsorption process is spontaneous in nature and spontaneity decrease with the increase in temperature.

In other words, practically there is a decrease in dye affinity and there are little or almost no significant changes in dye affinity with increase of dyeing temperature. Similar results were reported earlier in similar studies [21-24].

The kinetic parameters have been given in
Table 2. The $\mathrm{k}_{\mathrm{l}}$, and $\mathrm{q}_{\mathrm{e}}$ have been calculated from the slope and intercept of plots of log $\left(\mathrm{q}_{\mathrm{e}}-\mathrm{q}_{\mathrm{t}}\right)$ versus $\mathrm{t}$ according to pseudo-firstorder model (Fig .7) and versus $t$ according to pseudo-second-order model (Fig .8) $\mathrm{q}_{\mathrm{e}}$ and $\mathrm{k}_{2}$ from the slope and intercept have been calculated.

From Table 2, the correlation coefficient values for the pseudo-second-order rate equation 0.985 was found to be higher than the pseudo-first-order rate equation of 0.942 .

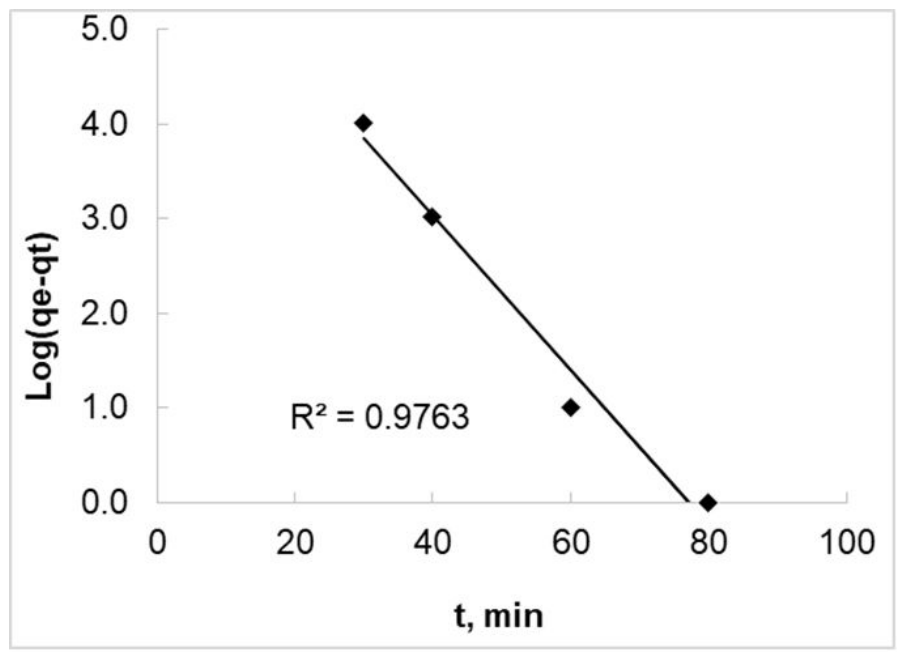

Figure 7. Pseudo-first-order plots for dyed cashmere

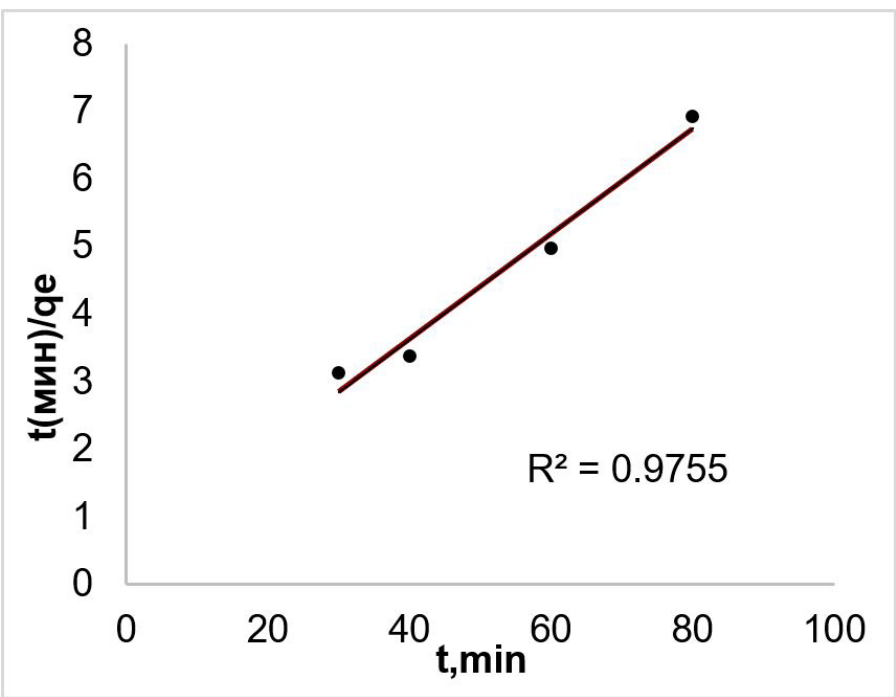

Figure 8. Pseudo-second-order plots for dyed cashmere (initial concentration of $630 \mathrm{mg} / \mathrm{l}, \mathrm{pH}=5.0, T=353 \mathrm{~K}$ ) 
In addition, the value of the absorption capacity calculated by the pseudo-second-order is in close proximity to the experimental value.

Table 2. Kinetic parameters for cashmere dyeing with Urtica cannabina L.

\begin{tabular}{|c|c|c|}
\hline \multirow{2}{*}{ Pseudo-first-order } & $\mathrm{k}_{1,}\left(\mathrm{~min}^{-1}\right)$ & $56.9 \times 10^{-2}$ \\
\cline { 2 - 3 } & $\mathrm{q}_{\mathrm{e}},\left(\mathrm{mg} \cdot \mathrm{g}^{-1}\right)$ & 16.57 \\
\cline { 2 - 3 } & $\mathrm{R}^{2}$ & 0.94 \\
\hline \multirow{3}{*}{ Pseudo-second-order } & $\mathrm{k}_{2,}\left(\mathrm{~g} \cdot \mathrm{mg}^{-1} \cdot \mathrm{min}^{-1}\right)$ & $11.92 \times 10^{-4}$ \\
\cline { 2 - 3 } & $\mathrm{q}_{\mathrm{e}},\left(\mathrm{mg} \cdot \mathrm{g}^{-1}\right)$ & 14.82 \\
\cline { 2 - 3 } & $\mathrm{R}^{2}$ & 0.982 \\
\hline Experimental value & $\mathrm{q}_{\mathrm{e}},\left(\mathrm{mg} \cdot \mathrm{g}^{-1}\right)$ & 15.07 \\
\hline
\end{tabular}

This indicates that cashmere dyeing process can be explained with pseudo-secondorder equation. These data suggest that the mechanism of adsorption of pseudo-secondorder is predominant and that the overall rate adsorption of Urtica cannabina L. dye's bio preparation is more likely to be controlled by the chemisorption process [25].
In fact, this was already anticipated due to the chemical attraction earlier discussed and it was also reported by Tserendulam and Das et al $[26,27]$.

\section{Dyeing isotherm}

The isotherms of cashmere dyeing are presented in Figure 9.

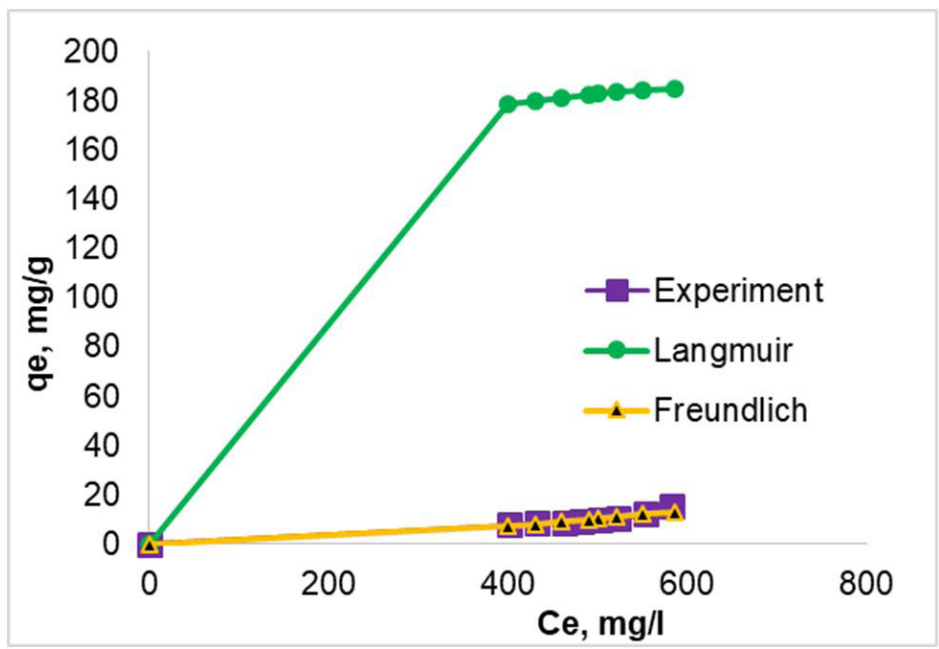

Figure 9. Nonlinear adsorption isotherm of Langmuir, Freundlich model and experimental values (initial concentration of $630 \mathrm{mg} / \mathrm{l}, \mathrm{pH}=5.0, T=353 \mathrm{~K}, t=40 \mathrm{~min}$ )

Cashmere dyeing is better adjusted to the Freundlich model according to the experimental data. The Freundlich model assumes a heterogeneous adsorption surface with sites that have different energies of adsorption and are not equal. It predicts the formation of multi-layers (Freundlich, 1906). Possibly, the monolayer occurs with the interaction between the hydroxyl groups of the dye and the amino groups of the protein fibres [25]. The multi-layer is formed through the chemisorption of other radicals that interact 
with the dye.

Therefore, the Freundlich model that emphasizes the importance of both phenomena comes naturally as the model that may represent the equilibrium data of the dyeing bio-preparation extracted from Urtica cannabina $L$. in the cashmere.

Parameters for the dyeing isotherm for cashmere dyeing are shown in Table 3.

Table 3.The theoretical parameters of isotherms for cashmere dyeing

\begin{tabular}{|c|c|c|}
\hline Isotherm model & Isotherm constants & Corbent: cashmere \\
\hline \multirow{2}{*}{ Langmuir } & $\mathrm{Q}^{0}, \mathrm{mg} / \mathrm{g}$ & 66.66 \\
\cline { 2 - 3 } & $\mathrm{b}$ & 0.0028 \\
\hline \multirow{2}{*}{ Freundlich } & $\mathrm{K}_{\mathrm{f}} 1 / \mathrm{g}$ & 3.68 \\
\cline { 2 - 3 } & $\mathrm{n}$ & 1.26 \\
\hline
\end{tabular}

Equilibrium data were fitted to the Freundlich model, which is in total agreement with the isotherm shape for dyeing cashmere.

\section{CONCLUSIONS}

With the increase in dyeing time, the dye uptake increases on cashmere up to 50 min of dyeing time and then gradually slows down and the dyeing process becomes stable. The best result of dyeing the cashmere was achieved using a temperature of $80^{\circ} \mathrm{C}, \mathrm{pH}$ 5.0, 60 minutes and initial dye concentration of extracted by water with an ML ratio of $1: 30$. Also the best result of bio-preparation extracting was achieved using a temperature of $80^{\circ} \mathrm{C}, 80$ minutes and ML ratio $1: 30$ by water of Urtica cannabina L. according to our experimental data $[12,28]$.

The thermodynamics parameters of cashmere dyeing are endothermic and spontaneous. Therefore, there will be an increase in dye absorption with an increase in temperature of dyeing after which the dyeing process slows down and dye adsorption at a certain temperature where equilibrium of dyeing is achieved. The kinetics of dyeing can be fitted by pseudo-second-order model as a correlation coefficients and values of the absorption capacity. The pseudo-secondorder model may successfully represent the kinetic experimental data for cashmere dyeing. According to the kinetic and equilibrium results, it was concluded that chemisorption is quite important in cashmere dyeing. The equilibrium data for cashmere fibre can be represented by the Freundlich model.

Considering that the dyeing process has a great contribution of chemisorption which promoted good colour fastness to laundering, it can be concluded that dyeing with Urtica cannabina $L$. has huge advantages as the textile waste water is much more biodegradable than the textile waste water generated with synthetic dyes. 


\section{REFERENCES}

[1] National Statistical Office of Mongolia. (2016, January 24). 12 аймаг малаа 5 төрлөөр өсгөсөн байна [5 Kinds of animals are raised in 12 aimags]. National Statistical Office of Mongolia. Retrieved January 12, 2016, from http://www.nso.mn/content/1\#.VMpQWJX9nmJ.

[2] Takahashi, H., Nyamsamba, D., Mandakh, B., Zagdsüren, Yo., Amano, T., Nomura, K., Yokohama, M., Ito, S., \& Minezawa, M., (2008). Genetic Structure of Mongolian Goat Populations using Microsatellite Loci Analysis. Asian Australasian Journal of Animal Sciences, 21(7), pp. 947-953. doi:10.5713/ajas.2008.70285.

[3] Gankhuyag, S. O., (2009). A Study on the Competitive Advantages of Cashmere Industry in Mongolia. Unpublished master's thesis, National Sun Yat-sen University, Kaohsiung. Javkhlantögs, N., Ankhbayar, [] E., Tegshjargal, K., Enkhjargal, D., \& Ganzorig, C., (2009). AFM Study of Untreated and Treated Fibres of Mongolian Goat Cashmere. Materials Science Forum, pp. 610-613 and 175-178. doi:10.4028/www. scientific.net/MSF.610-613.175.

[4] McGregor, B. A., (2012). Properties, Processing and Performance of Rare Natural Fibres: A Review and Interpretation of Existing Research Results. Canberra: Rural Industries Research and Development Corporation (RIRDC).

[5] Ahlström, L/. H., Eskilsson, C. Sparr, Björklund E., Determination of Banned Azo Dyes in Consumer Goods. TrAC Trends AnalChem 2005;24: pp. 49-56.

[6] Shahid, M., Shahid-Ul-Islam, Mohammad, F., Recent Advancements in Natural Dye Applications: A Eeview. J Clean Prod 2013;53:310-31.

[7] Islam S, Shahid, M., Mohammad, F., Perspectives for Natural Product-based Agents Derived from Industrial Plants in Textile Applications - A Eeview. J Clean Prod 2013; 57: 2-18.

[8] Yusuf, M., A., M., Khan, M. I., Khan, S. A., Manzoor, N., et al. Assessment of Colorimetric, Antibacterial and Antifungal Properties of Woolen Yarn Dyed with the Extract of the Leaves of Henna (Lawsoniainermis). J Clean Prod 2012; 27: 42-50.

[9] Bechbold, T., Mussak, R., Handbook of Natural Colorants. John Wiley\&Sons Ltd, England. 2009.

[10] Khaidav, T. S., Altanchimeg, B., and Barlamova, T. C., 1985. Medicinal Plants of Mongolian Medicine. State publishing, Ulaanbaatar, pp. 8-40.

[11] Ligaa, V., and Gal, Z. H., 2000. Resources of Economical Useful Plants of Mongolia. Paper presented during the International Conference on Central Asian Ecosystem, Ulaanbaatar.

[12] Tserendulam, S., Delgermaa, S., Nadmid, G., Soyol-Undrakh, Kh., Tamara, M., Eco-friendly of Cashmere Dyeing with Rheum Undalitum L. and Urtica Cannabina L. 2017, $11^{\text {th }}$ International Forum on Strategic Technology. IFOST 2017. Korea.

[13] Gui-zhen, K., Weli-lin, X., Wei-dong, Y., [2008] Thermodynamic and Kinetic Studies of Adsorption of Berberine on Silk. Indian J Fibre Text Res 33: pp. 185-188.

[14] Koyuncu, M., [2012]. Thermodynamic Parameters and Kinetics of Wool Yarn with Aqueous Extract of rubiatincorum.L. IIOABJ.Vol.5; Issue 2; pp. 12-15.

[15] Yusan, S., Gok, C., Erenturk, S., Aytas, S., [2012] Adsorptive Removal of Thorium (IV) using calcined and flux calcined diatomite from Turkey: evaluation of equilibrium, Kinetic and Thermodynamic Data. Applied clay sci 67-68: pp. 106-116.

[16] Samanta, A. K., Konar, A., Chakraborti, S., Datta, S., [2011] Dyeing of Jute Fabric with Tesu Extract: Part I - Effects of Different Mordant's and Dyeing Process Variables. Indian J Fibre Text Res36: pp. 63-73.

[17] Kumersan, M., Palansisam, J., Kumar, P. E., [2012] Application of Eco-friendly Natural Dye on Cotton using Combination of mordant's. Indian J Fibre Text Res 37: pp. 194-198.

[18] Al- Ghouti, M. A., Khraished, M. A. M., Allen, S. J., Ahmet, M. N., [2003] The Removal of Dyes from Textile Wastewater as Study of the Physical Characteristics and Adsorption Mechanisms of Diatomeceous Earth. J Environman69 (3): pp. 229-238.

[19] Arora, A., Deepali, R., Deepti, G., Gulrajani, M. L., [2012] Dyeing Parameters of Hydroxylnaphthoquinones Extracted from arnebianobilisrech.f. Indian J Fibre Text Res 37: pp. 91-97. 
[20] Koyuncu, M., Thermodynamic Parameters and Dyeing Kinetics of Wool Yarn with Aqueous Extract of Rubiatinctorum L. IIOABJ; Vol. 5; Issue 2; 2014. pp. 12-15.

[21] Chairat, M., Rattanaphani, S., Bremner, J. B., Rattanaphani,V., An Adsorption and Kinetic Study of Lac Dyeing on Silk. Dyes and Pigments; 64, pp. 231-241. DOI:10.1016/j.dyepig. 2004. 6.009.

[22] Das, D., Maulik, S. R., Bhattacharya, S. C., Dyeing Wool and Silk with Bixa Orellana.2007. Indian Journal of Fibre and Textile Research. 2007. Vol. 32. pp. 366-372.

[23] Kumersan, M., Palansisam, J., Kumar, P. E., [2012] Application of Eco-friendly Natural Dye on Cotton using Combination of Mordant's. Indian Journal of Fibre and Texttile, Res 37: pp. 194-198.

[24] Al-Ghouti, M. A., Khraished, M. A. M., Allen, S. J., Ahmet, M. N., [2003] The Removal of Dyes from Textile Wastewater as Study of the Physical Characteristics and Adsorption Mechanisms of diatomeceous Earth. J. Environment. 69 (3): pp. 229-238.

[25] Vinod, K. N., Puttaswamy, Gowda, K. N. N., Sudhakar, R., Isolation of Colour Components from Flowers of Tabebuia argentea: Kinetic and Adsorption Studies on Silk Yarn. Coloration Technology. 2011. 127. pp. 205-209. DOI: 10.1111/j.1478-4408.2011.00300.x

[26] Tserendulam. S., Nadmid. G., Ganchimeg, Yü., "Studies of Kinetics and Thermodynamic Parameters of Cashmere Dyeing with Bio-Preparation of Rheum Undalitum L.". International Journal of Engineering Trends and Technology (IJETT). January 2018. Vol 55 (3). ISSN:2231-5381. pp. 135141. DOI:10.14445/22315381/IJETT-V55P225.

[27] Das, D., Maulik, S. R., Bhaattacharya, S. C., Dyeing Wool and Silk with Bixa Orellana.2007. Indian Journal of Fiber and Textile Research. 2007. Vol. 32. pp. 366-372.

[28] Tserendulam, S, Nadmid, G., Delgermaa, S. "Dyeing, Fastness And UV Protection Properties Of Cashmere Fabric Dyed With Some Plant Bio-Preparations". International Journal of Engineering Trends and Technology (IJETT). January 2018. Vol 55 (3). ISSN:2231-5381. pp. 126-133. DOI: 10.14445/22315381/IJETT-V55P224. 